\title{
Alcoholism and Depression
}

\author{
G. Dodig, R. Brnabić, D. Mrass, M. Žuljan-Cvitanović, Z. Katavić, \\ Č. Lončar and B. Uglešić
}

Department of Psychiatry, University Hospital »Split«, Split, Croatia

\begin{abstract}
A B S T R A C T
Alcoholism and depression are entangled in many ways and appear in many combinations. In spite of this fact, to this problem is rarely given sufficient attention which results in poor diagnostic and inadequate therapeutic approach with all the consequences this engenders. The frequency of depression in alcoholics is investigated here with the object of finding out to what extent it can be successfully diagnosed and medically treated. The research was carried out in the Psychiatric Clinic of the Clinical Hospital »Split" and the sample of examinees included the patients treated in the stationary part of the Clinic and in the daily hospital.
\end{abstract}

\section{Introduction}

Alcoholism is featured by abnormal behavior including craving for alcohol and a poor control over drinking. The principal phenomena related to the development of alcoholism include tolerance as well as physical and mental addiction. These phenomena contribute to the sense of "pleasure " produced by alcohol, to constant drinking and in the last resort to the development of alcoholism ${ }^{1}$.

Disturbances related to depression are featured by a high rate of morbidity and disability as well as a high death rate, which makes depression one of the serious problems of contemporary society $^{2}$. Depression is a pathological change in disposition; it is an emotional illness.
Depression has become a characteristic of our age, and the syndrome of depression is a "normal " manner of reaction of the contemporary man/woman. Depression as an inseparable part of the contemporary human being, it has become a civilizational disorder which makes up the »cultural atmosphere of our time ${ }^{3}$.

The term "depression" has three meanings in psychiatry because we may have to do to a symptom, to a syndrome or to a nosological entity. The basic element of depression is its phenomenological aspect characterized by a disturbance or poor disposition tending to sadness. This central symptom is surrounded by others contributing to the description of the whole entity ${ }^{4}$. 
The unique structure of a syndrome of depression encompasses the sphere of volition, thought emotions and the entire personality. A change of mood as a fundamental disturbance is accompanied by an overall inhibition and a sense of moral pain. An essential feature of depression is an undisturbed awareness of the illness in those suffering from it. They have a sense authenticity, which causes them additional pain.

The interconnectedness of depression and some other illnesses was established a long time ago $^{5}$. Each bodily illness may be accompanied by a certain amount of depression, by worry, insecurity, inconfidence or fear. The intensity and the character of these traits greatly depend on how serious the bodily illness is, but also on the personality of the patient before the illness (various mental experiences contributing to the organization of the personality in every phase of its development from infancy to maturity). Clinical observation has pointed to some illnesses in which the accompanying features of depression are particularly strongly expressed, which naturally makes the diagnostic and especially the therapeutic treatment much harder and the prognosis of the illness much worse. This particularly relates to alcoholism: it is a complex condition which, beside addiction which is its essential feature, results in various bodily damages.

A higher frequency of depression among alcohol addicts than among other populations has been confirmed with certainty. Co-morbidity of alcoholism and depression varies from $16 \%$ to $68 \%^{5-8}$.

Ross and collaborators ${ }^{9}$ have found a prevalence of $24.4 \%$ of serious depression in alcoholics. In spite of such high prevalence of depression in alcohol addicts, however, the nature of the relationship between depression and alcohol addiction is hard to define. The status of drinking also seems to have some significance.
The aim of the paper is to determine the frequency and seriousness of depression in alcohol addicts and to establish to what extent this "co-morbidity" is being diagnosed.

\section{Patients and Methods}

A group of 62 patients admitted to the Psychiatric Clinic "Split« in an acute state of drunkenness has been examined. Most of them were men (56 i.e. 90,3\%) while $9.7 \%$ were women (only 6 ). None of the examinees were suffering from any other mental illness or psycho-organic syndrome neither were they taking any other psychoactive substance. They were between 28 and 64 years of age.

Following a clinical treatment and an interview (social, working and alcoholic history) the mental status of all examinees was determined. After the sobering of the patients an examination according to Hamilton's scale ${ }^{10}$ for depression was carried out. A re-examination was carried out after three weeks of abstinence.

\section{Results and Discussion}

At the first examination (preceding abstinence) from total of the 62 patients, 56 (or 90\%) were suffering from depression and only 6 patients (or 10\%) did not suffer from depression.

The intensity of depression was established in due course. Out of numerous instruments applicable here we have opted for Hamilton's scale, where 17 »items" were evaluated by scores $0-2-4$, and the total score denotes the intensity of depression.

We did not consider the values up to 12 to be relevant, so those examinees were nor deemed to be suffering from depression. Scores within the range 12-17, are considered symptomatic for a mild type of depression. Score values from 18 to 24 are denoted as having moderate de- 
pression, while the patients with scores over 24 are considered to be suffering from serious depression. In accordance with those data the intensity of depression is considered to be mild (score 12-17) in 18 patients $(29 \%)$, moderate (score 18-24) in 22 patients $(35.5 \%)$ and serious (score over $24)$ in $16(25.8 \%)$ patients. Proportions of patients according to the degree of depression before abstinence (at the first examination) are shown at Figure 1.

In the course of further monitoring the examinees underwent hospital treatment including strict abstinence. After three weeks they were re-examined with the following results. The numbers of patients according to the degree of depression before and after the period of abstinence are presented at Table 1 . It is evident that out of 56 patients suffering from de- pression before abstinence 26 patients did not show any signs of depression after three weeks' abstinence. This proves a direct connection between depression and alcohol intake.

The next thing to do was to determine the intensity of depression. We found out that the intensity of depression had decreased in all examinees with the average fall of score value 9.8. The reduction of score value following three weeks' abstinence proved to be statistically significant.

Table 2 presents the differences of two groups of alcoholic patients with and without symptoms of depression with respect to age, sex and Hamilton's scores scores values. It is evident that the two presented groups made up according to score do not differ in terms of age (Age: no

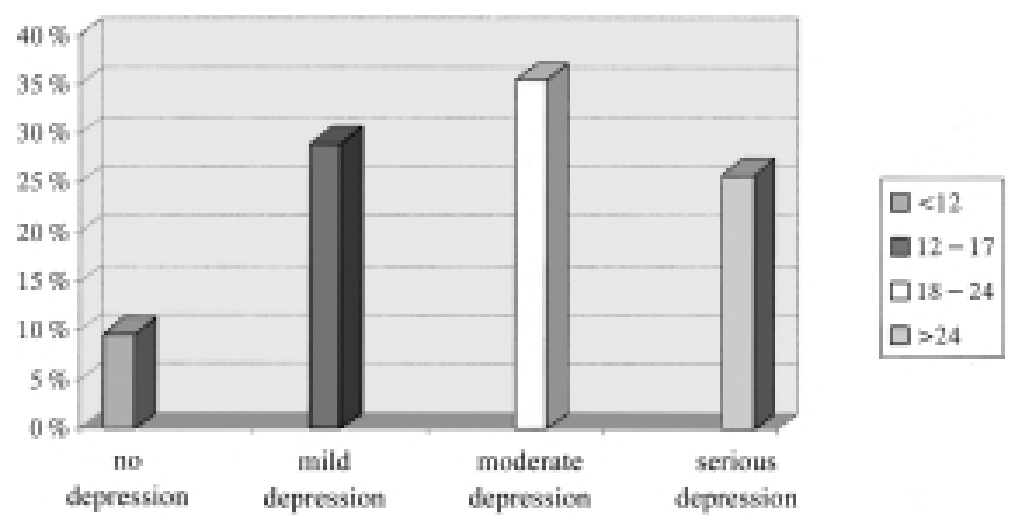

Fig. 1. Proportion of patients according to the degree of depression before abstinence (at the first examination).

TABLE 1

NUMBER OF PATIENTS ACCORDING TO DEPRESSION TYPE BEFORE AND AFTER THE PERIOD OF ABSTINENCE

\begin{tabular}{lcc}
\hline & Before abstinence & After 3 weeks' abstinence \\
\hline Suffering from depression & 56 & 30 \\
No signs of depression & 6 & 32 \\
Total & 62 & 62 \\
\hline
\end{tabular}


TABLE 2

MEAN VALUES OF AGE AND HAMILTON'S SCORES VALUES IN GROUPS OF ALCOHOLIC PATIENTS WITH AND WITHOUT SIGNS OF DEPRESSION AFTER THREE WEEKS OF ABSTINENCE

\begin{tabular}{lccl}
\hline & $\begin{array}{c}\text { No depression } \\
(\mathrm{N}=23)\end{array}$ & $\begin{array}{c}\text { With depression } \\
(\mathrm{N}=30)\end{array}$ & $\mathrm{p}$ \\
\hline Age (years) & 41.3 & 44.7 & 0.26 \\
Score & 18.3 & 26.2 & $0.003^{*}$ \\
\hline
\end{tabular}

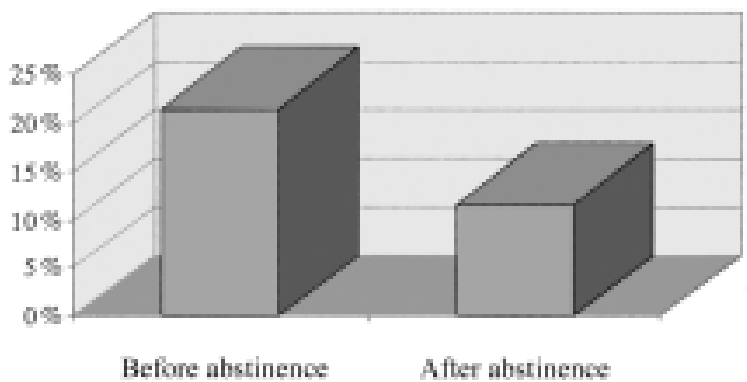

Fig. 2. The average Hamilton's scores value before abstinence and after three weeks of abstinence.

depression $=41.3$, with depression $=44.7$ $(\mathrm{p}=0.26)$; Score: no depression $=18.3$, with depression $=26.2(\mathrm{p}=0.003)$ ).

The averaged Hamilton's scores values before abstinence and after three weeks of the abstinence are shown on Figure 2. It is evident that all the patients without depression previous to abstinence have remained in the same group after three weeks. All the patients with mild depression have entered the group without depression.

From the group with moderate depression 4 patients (or 18\%) have remained in the same group while 14 of them (64\%) have entered the group with mild depression while 4 patients (18\%) have entered the group with no depression. From the group suffering from serious depression 4 patients (or 25\%) have entered the group with moderate depression, 8 of them (50\%) have entered the group with mild depression, and $4(25 \%)$ have entered the group with no depression.

From the established facts it is possible to draw the following conclusions. Our investigation has shown that the frequency of depression in alcoholics is very high and that it amounts to $90 \%$. The proportion of patients suffering from serious depression is $25.8 \%$. We have proved that the degree of depression is directly related to the drinking status and that abstinence leads to considerable improvement of the psychical condition.

\section{R E F E R E N C E S}

1. LANG, B., Alcoholism. In: MUAČEVIĆ, V. (Ed.): Psychiatry. (In Croat.) (Medicinska naklada, Zagreb, 1995). — 2. HOTUJAC, LJ. Affective disor-

ders. In: MUAČEVIĆ, V. (Ed.): Psychiatry. In Croat. (Medicinska naklada, Zagreb, 1995). - 3. UGLEŠIĆ, B., Krka u medicini i farmaciji, 23 (1990) 3. - 4. 
SHAW, D. M.: Handbook of affective disorders. (The Boots Company PLC, 1984). - 5. HALIKAS, J. A., M. A. HERZOG, M. M. MIRASSOU, Psychiatric diagnosis among female alcoholics. In: GALANTER, G. (Ed.): Currents in alcoholism. Vol. 8. (Grune \& Stratton, New York, 1981). - 6. POWELL, B. J., E. C. PENICK, E. OTHMER, J. Clin. Psychiatry, 43 (1982)
404. - 7. HASSELBROCK, M. N., R. E. MEYER, J. J. KEENER, Arch. Gen. Psychiatry, 42 (1985) 1050. - 8. HERZ, L. R., L. VOLICER, N. D'ANGELO, Compr. Psychiatry, 30 (1990) 72. - 9. ROSS, H. E., F. B. GLASER, Arch. Gen. Psychiatry, 45 (1988) 1023. - 10. HAMILTON, M., J. Neurol. Neurosurg. Psychiatry, 23 (1959) 56.

\section{G. Dodig}

Department of Psychiatry, University Hospital »Split«, Spinčiceeva 1, 21000 Split, Croatia

\section{ALKOHOLIZAM I DEPRESIJA}

\section{S A Ž E T A K}

Ko-morbiditet alkoholizma i depresije isprepleće se na brojne načine i javlja u raznim kombinacijama. Unatoč toj činjenici, ovom problemu se rijetko poklanja dostatna pozornost, što rezultira manjkavim dijagnostičkim, a nakon toga i neadekvatnim terapijskim pristupom sa svim posljedicama koje iz toga proizlaze. U ovom istraživanju prikazana je učestalost depresije u alkoholičara, u kojoj mjeri se to stanje uspješno dijagnosticira i konačno, na koji se način ovakvi bolesnici liječe. Istraživanje je izvršeno u Klinici za psihijatriju Kliničke bolnice »Split«. U istraživanje su bili uključeni bolesnici liječeni u stacionarnom dijelu Klinike i u dnevnoj bolnici. 